\title{
Some Lexical Aspects of Cape Muslim Afrikaans
}

\author{
Achmat Davids, Southern African Research Program, Yale University, \\ Connecticut, USA
}

\begin{abstract}
It is a relatively well known fact that Cape Muslim Afrikaans has its own distinctive pronunciations which at times differ sharply with that of Standard Afrikaans. What is not so well known, is that apart from its core vocabulary, which is derived from Dutch, Cape Muslim Afrikaans also has a distinctive lexical inventory, created to essentially extend the limitations of the nineteen th century Cape Afrikaans. This essay looks at some aspects of that inventory.
\end{abstract}

Retained within this distinctive lexical inventory are many lexical units which were discarded from Standard Afrikaans during the process of standardization. Cape Muslim Afrikaans also inherited some of its unique lexical units from the Malayo-Polynesian languages of the slave ancestors of the Cape Muslim community, while its vocabulary was further extended by borrowings from the languages of contact, English and French. Lexical items from Arabic came into its lexicon as a result of the translation of Arabic theological and theo-philosophical tracts into the Afrikaans mother tongue of this community.

This essay looks at how the lexical inventory of Cape Muslim Afrikaans was disseminated and perpetuated in the Cape Muslim community. It looks at the role of the literary tradition of ArabicAfrikaans and the Islamic religious education system at the Cape in this regard. Of particular interest are the changes which occur in the orthoepic nature and syntactical function of inherited and borrowed lexical units, by the affixing of lexical or grammatical morphemes, so that these units conform to the acoustic nature of Cape Muslim Afrikaans. The creation of composites and neologisms are also explored, while lists of inherited lexical units, with etymological origin, and more complex lexical items are provided.

Keywords: CAPE MUSLIM AFRIKAANS, LEXICAL ASPECTS, CORE VOCABULARY, INHERITED AND BORROWED ITEMS, STANDARD AFRIKAANS, ARABIC AFRIKAANS, ARABIC ORTHOGRAPHY, DUTCH, ENGLISH, CREOLIZATION, SLAVE LANGUAGES, RELIGIOUS EDUCATION, NEOLOGISMS, SYNTACTICAL FUNCTION, PRONUNCLATION, IDIOMS AND EXPRESSIONS

Opsomming: Enkele leksikale aspekte van Moesliemafrikaans. Dit is goed bekend dat Kaapse Moesliemafrikaans soms in uitspraak van Standaardafrikaans verskil. Wat nie so bekend is nie, is dat Kaapse Moesliemafrikaans benewens sy basiese woordeskat van Hollandse oorsprong, ook 'n kenmerkende leksikale inventaris het wat geskep is om veral die beperkings van die negentiende-eeuse Kaapse Afrikaans te bowe te kom. Dit is aspekte van hierdie inventaris wat hier bespreek word. 
Hierdie kenmerkende leksikale inventaris sluit baie leksikale eenhede in wat oorleef het na die standaardisering van Afrikaans. Kaapse Moesliemafrikaans sluit ook leksikale erfgoed in van die Maleis-Polinesiese tale wat deur die slawevoorvaders van die Kaapse Moesliemgemeenskap gebesig is. Sy woordeskat word verder uitgebrei deur leengoed uit Engels en Frans, tale waarmee kontak gemaak is. Woorde is aan Arabies ontleen as gevolg van die vertaling van godsdienstige en teo-filosofiese geskrifte in die Afrikaanse moedertaal van hierdie gemeenskap.

Die opstel bespreek die oordrag en oorlewing van die inventaris van Kaapse Moesliemafrikaans in die Kaapse Moesliemgemeenskap. Die rol van die skryftradisie van Arabies-Afrikaans en die geloofsonderrig in dié verband word bespreek. Van groot belang is die aanpassing van die uitspraak en sintaktiese funksies van die leengoed en erfgoed by die akoestiese karakter van Kaapse Moesliemafrikaans deur die toevoeging van leksikale en grammatiese morfeme. Die skepping van samestellings en neologismes word ondersoek, terwyl lyste van oorgeërfde leksikale eenhede, met hul afleidings, en meer komplekse leksikale items voorsien word.

Sleutelwoorde: KAAPSE MOESLIEMAFRIKAANS, LEKSIKALE ASPEKTE, KERNWOORDESKAT, ERFGOED EN LEENGOED, STANDAARDAFRIKAANS, ARABIESE AFRIKAANS, ARABIESE ORTOGRAFIE, NEDERLANDS, ENGELS, KREOLISERING, SLAWETALE, GELOOPSONDERRIG, NEOLOGISMES, SINTAKTIESE FUNKSIE, UITSPRAAK, IDIOME EN UITDRUKKINGS

\section{INTRODUCTION}

One of the distinctive features of the Cape Muslim Afrikaans variety is its peculiar pronunciation of certain Afrikaans words. There is a noticeable tendency among Cape Muslim Afrikaans speakers to pronounce the Afrikaans diphthong $u i$ [oey] as $e i$ [əi]; or, at times, to use $g a$ [xa] instead of the Standard Afrikaans ge $[x a]$ for the past tense of the verb; or to change the pronunciation of a double $d$ or $t$ in the middle of a word to $r$. Thus words like middag, middel and bottel tend to be pronounced as marrag [marax] and mirril [məral] and borrel [boral] respectively. These distinctive features of the acoustic nature of Cape Muslim Afrikaans, the Afrikaans used by the Muslim community of the Western Cape, but especially in the Bo-Kaap, is relatively well known.

But this tendency in pronunciation is already known to have existed in the nineteenth century spoken Afrikaans or Cape Dutch. One need only to look at Abubakr Effendi's Bayânudin (An Explanation of the Religion) written in 1869, to recognize this fact. A typical example is Changuion (1844: xix) paddak which appears as padak in the Bayânudîn (Effendi 1869: 296). There are, however, other examples of Cape Dutch or nineteenth century A frikaans pronunciations which have lingered on in Cape Muslim Afrikaans. Examples of these are danebol and moddras for the Standard Afrikaans dennebol and modder. These words, with morphological structures which conform to their pronunciation in Cape Muslim Afrikaans, are already listed by Changuion in 1844 (see 
Changuion 1844: $x \mathrm{i}$ and xviii) and continue to be pronounced in this mode in Cape Muslim Afrikaans.

Many of the distinctive features of the acoustic nature of Cape Muslim Afrikaans could be attributed to the use of the Arabic alphabet to transcribe the sounds of the essentially Western Germanic language they were speaking. The Arabic alphabet could not convey all the sounds of their Afrikaans mother tongue. Not even the use of the Arabic phonetic script, which became their preferred alphabet for writing, could bridge this inadequacy. The inadequacy of the Arabic orthography to represent distinctive Afrikaans sounds, therefore, greatly influenced their orthoepic practice. This I illustrated by the morphological changes which occurred in the Arabic writing form of the simple Afrikaans word hulle at different times in the development of Arabic-Afrikaans (Davids 1991). These historical morphological changes are illustrated in Figure 1.

\begin{tabular}{|c|c|c|c|c|c|c|}
\hline 1869 & — hoewaile & - & [huvailə] & 一 & - & Abukakr Effendi \\
\hline 1894 & - hee-le & 一 & [he:li] & 一 & - & Hisham N. Effendi \\
\hline 1907 & - hile & 一 & [həle] & - & & Abdurahim Al Ira \\
\hline 1910 & - hil-i & - & [halə] & - & & Ta Ha Gamieldien \\
\hline
\end{tabular}

Figure 1: A historical pattern in morphological and orthoepic changes in the word hulle

Apart from its acoustic nature and orthoepic practice, Cape Muslim Afrikaans has some distinctive words which make its vocabulary different from Standard Afrikaans. Some of these words existed in the vocabulary of Cape Afrikaans or Cape Dutch long before its standardization. Words such as uiwe (onions), maskie (eventhough), ver-effe (a little while ago), and werksloon (good deeds) (Elffers 1908: 39ff), were already in use prior to the establishment in 1875 of the Genootskap van Regte Afrikaners, the organisation which first actively promoted Afrikaans as a language.

Similarly, words such as rieziek-giever (giver of bounty), opbouwens (systematic construction), slamblie-er (used as a noun - slaughterer, but from the Malayu verb slamblee, to which the Afrikaans grammatical morpheme er is added to form the noun) are regularly encountered in the Arabic-Afrikaans publications ${ }^{1}$ produced prior to 1900 (Davids 1991). These words, together with Malayu words such as ghielap [xilap] (from the Malayu kilat for light- 
ning), ghoentoem [guntum] (from the Malayu guntur - thunder); manniekamer (from the Malayu kammar-mandi - bathroom) or simply djamang (toilet) or graa-na (eclipse) which had acquired a distinct Afrikaans pronunciation, were already strongly bridged into the Afrikaans of the Cape Muslims in the nineteenth century (Muller 1960: 38). Then there are older words such as kasm (oath), listed by Swaving (1830: 336) and memme (foster mother), listed by Teenstra (1830: 348) which were already in use in the 1820s, and which show the tremendous influence of the ancestral languages of the slaves on the spoken Afrikaans of the Cape Muslims. These words, which are still in daily use by a vast section of Afrikaans speakers, have never been absorbed into the vocabulary of Standard Afrikaans.

\section{THE PERPETUATION OF DISTINCTIVE LEXICAL UNITS AND ITEMS}

That these words continued to be used in Cape Muslim Afrikaans, in both secular and religious settings, could be attributed to their extensive use in the Arabic-Afrikaans publications. Many of these publications were used as readers in the Muslim religious schools or madaris (singular $=$ madrasah), or their contents constituted part of the text of a sermon or lecture delivered at the mosques. These words were also incorporated into the koples, the rote learning formulations or lessons, which the madrasah students had to memorize and recite, i.e. literally get into their heads.

It is the normal practice for these learning formulations to be dictated by a teacher or written on a chalkboard and transcribed by the student into a notebook called the koples boek. The student is then required to memorize the learning formulation and recite it from memory in the presence of the teacher on the next day. If the student recites the lesson proficiently, a new learning formulation or lesson is given and the process repeated. It is interesting to note how this process in itself lends two lexical items to Cape Musl im Afrikaans.

The process of memorization is called faam-maak, a composite of two lexical morphemes from two different languages - faam, from Malayu, and maak from Afrikaans. As a verb, faam-maak is so strongly bridged into Cape Muslim Afrikaans that it even takes on a past tense form, faamgemaak. The process of proficiency in recitation or recall is called lanja, an inherited Malayu lexical item. Thus in Cape Muslim Afrikaans it is not uncommon to hear: Hy het die storie goed faamgemaak, en is so lanja as hy dit vertel, dat jy nie wiet (weet) of dit die waarheid is nie.

But be that as it may, the same learning formulations continued to be used from generation to ${ }^{\circ}$ generation since the early nineteenth century. From some of these recorded formulations in student notebooks or koples boeke of the 1840 s and 1860 s, some of the etymological roots of some very frequently used Cape Muslim Afrikaans words could be traced. It also demonstrates the creolization which has occurred in Dutch, and from which creolized form Afri- 
kaans emerged. A passage from one of the 1860 koples boeke in my possession reads as follows:

Vierghiefnies van al die koewaat (evil) ... wai viersoek van Oeai wietienskap van ghoet en koewaat ... wai ghoeloef oeai ies maar een, oeai hiet niet ghalaikienies miet gha-nie-saam-nie (nobody, Afrikaans = niemand nie) ... wai bierou van al die koewaat. Wai loe-waister oeai ghiebot ... wai ghoeloef in wat wai miekeer dit ghief oeai, wai viersoek van oeai a-leen wat ghoet ies vier ons ...

From this short passage the nineteenth century etymological roots of such Cape Muslim Afrikaans words like ghaniemand (nobody: Standard Afrikaans = niemand); ghawietenskap (used in the sense of 'knowledge'; Standard Afrikaans = kennis) and ghaleikenis (equal; Standard Afrikaans gelyke) could be traced. It is obvious that ghaniemand is derived from gha-nie-saam; ghawietenskap is derived from wietenskap, and galeikenis is derived from ghalaikienies, as they appeared in their nineteenth century usage in the passage above. It is also very evident that the sentence "Allah ta "aalaa het nie ghaleikenis nie" (God the most high has no partner), which is frequently used in Bo-Kaap madaris, has its origin in the nineteenth century.

It was thus through the madaris or Muslim religious schools that the distinctive lexical units and items of Cape Muslim Afrikaans were transmitted and perpetuated. Though the medium of instruction in the madaris over the years was Afrikaans, this Afrikaans was not infrequently laced with lexical units or items borrowed or inherited from the ancestral slave languages of the Cape Muslim community. It is a known fact that as a result of their diversity of origins, the eastern slaves brought with them seven main languages and fourteen dialects (Crawfurd 1820). These languages and dialects were of the Malayo-Polynesian family. The slaves from Africa again brought with them a variety of Portuguese creoles (Valkhoff 1971), while Malayo-Portuguese was the trading lingua franca in the south east Asian Archipelago prior to the arrival of the Dutch (Bird 1883: 19-21). Of these languages, Malayu, and its distinctive Arabic script, known as Jawi, came to predominate at the Cape from the beginning of the nineteenth century. Archival evidence, however, indicates that not only Malayu but Sunda, Buganese and Macassar were also written at the Cape (Davids 1991).

The dominance of Malayu from the end of the eighteenth century, and its use as the first medium of instruction at the first slave madrasah in Dorp Street (Davids 1990), explain the more frequent borrowing or inheritance of lexical units and items from this language. It is impossible to think of madrasah or Islamic religious education at the Cape without three distinctive Malayu terms - batja, meaning to read; ai-ya, meaning to spell, and toellies, meaning to write. These three lexical units are very strongly wedged into the spoken Afrikaans of the Cape Muslim community. However, Malayu, though the most dominant, was not the only slave language from which lexical items were 
borrowed or inherited by Cape Muslim Afrikaans. In Standard Afrikaans, too, we can trace the etymological roots of the word tronk (prison) to tarunka, a Buganese and Sunda word. The word tronk could thus have come into Afrikaans through the Buganese and Balian slaves (Davids 1990).

Then too, as is the custom with the translation of Arabic religious works in most non-Arabic speaking Muslim communities, no effort was made to translate the keywords or fundamental concepts of Islamic thought (Brandel-Syrier 1960: xxxvi) in the Arabic-Afrikaans publications or at the madaris. Some of these keywords or fundamental concepts became part of the vocabulary of the Afrikaans of the Cape Muslim community, taking on different grammatical functions through the affixation of Afrikaans grammatical or lexical morphemes. Thus, for example, the Arabic word saheeh (correct), a noun, with the addition of the Afrikaans grammatical morpheme ste, becomes saheehste (the most correct) [sage:gsta], an adverb of degree. Similarly, the Arabic words salaah (prayer) and hoekoem (ruling) [gukum], by the affixing of an $s$ (the Afrikaans plural-forming grammatical morpheme) become salaats and hoekoems (Afrikaans plural forms). Sometimes an Arabic word assumes a new Afrikaans grammatical function by being coupled with an Afrikaans lexical morpheme to form a composite. Hence the Arabic word zakaat (charity) is coupled with the Afrikaans word maker to form the composite, zakaatmaker, meaning 'the giver of charity'.

Through the Arabic-Afrikaans publications and their language usage in the madaris some interesting lexical items and linguistic features of the Afrikaans of the Cape Muslims were transmitted and perpetuated in the community. The majority of these linguistic features and lexical items are still noticeable and present in the spoken Cape Muslim Afrikaans. This despite the exposure of this community to the Standard Afrikaans usage in secular schools and via radio and television. The continued existence of these linguistic features and lexical items, I attribute to the ease with which they help to facilitate communication. These linguistic features and items have within themselves a degree of originality and, at the same time, a communal relatedness. Hence, what they might lack in sophistication is nevertheless made up for by their usefulness for communication and linguistic creativity.

But then, too, their transmission is not in isolation of the human element. These linguistic features and lexical items are perpetuated, with all the nuances of the community's distinctive humour, through the madrasah and even the mosque. It was thus at madrasah that my six-year old niece, nurtured in an English speaking home environment, came to learn the lexical item "Is jou brein dan ghamaniengal?" (Are you really that stupid?), and uses it freely and with great humour, even with adults, who fail to comprehend what she considers to be elementary. 


\section{BUILDING A FUNCTIONAL VOCABULARY}

It was in the Dutch linguistic milieu that Afrikaans emerged. Dutch, therefore, provided the essential core vocabulary of the Afrikaans language. When the Cape Muslim Arabic-Afrikaans writers embarked on the process of writing their Cape Dutch mother tongue in Arabic script, they sincerely believed that they were writing Dutch. This is evident from the use of the Dutch wij (wai in Arabic script) instead of the Afrikaans ons in the passage from the 1860 koples boek above. What they were in fact writing, as already noted, was a creolized Dutch, a form of Dutch which had already moved away from the pristine purity of the original language.

This creole form of Dutch, from which Afrikaans emerged, and which was of great concern to Changuion (1844), was essentially a lower class language (De Lima 1844: 9) in the nineteenth and early twentieth centuries. It had a rather restricted and limited vocabulary. Or, as Elffers (1908: 5) puts it, "a language fit for daily use, though lacking in expression for modern ideas, as well as in technical terms". In fact, Cape Dutch or Afrikaans was, at the end of the nineteen th century, considered by some to be too simple a language with no literary future. This view was clearly articulated by the colonial linguist, Theophilus Hahn (SABP: 1882), in a paper he read at the South African Public Library on 29 April 1882 . He said further:

It can hardly be expected that the descendants of the Malayo-Polynesian slaves and Hottentot servants, who originally spoke an agglutinative tongue, will have any improving influence on an inflecting language.

Dr Theophilus Hahn saw Cape Dutch or Afrikaans as essentially the language of people of colour who were resident at the Cape. It was transmitted by them to whites on isolated farms and those white children they served as "nurses and ayahs".

This notion of Cape Dutch as essentially an "uncultured patois" (Logeman 1903), was a popular one at the time. It contributed considerably to Afrikaans ultimately acquiring the derogatory nicknames of "kombuistaal" and "Hotnotstaal". At the same time it revealed the negative race relations which prevailed at the Cape.

This perceived limitation of the Afrikaans or Cape Dutch vocabulary did not prevent the Cape Muslim Arabic-Afrikaans writers to embark on the translation of involved theological and theo-philosophical Arabic works. One of the wonders of these translations is that, despite the limitation of the vocabulary at their disposal, these translators managed to capture the spirit of the work they translated, and rendered it in a language which has remained meaningful even to the present generation of Cape Muslims. Then, too, the easy and simple language used, did neither distort, nor diminish, nor distract from the meaning of the original text. 
In the process of translating, these writers were required to build a functional vocabulary, a vocabulary which must not only be able to express the thoughts of the authors they were translating, let alone their conveying their own nuances, but which will be understood and be meaningfully real to their prospective readers. It was in this process of vocabulary building, as we shall see in the course of this essay, that the genius of the Cape Muslim Arabic-Afrikaans writers really came to the fore.

From the words and word constructions in the Arabic-Afrikaans publications, it becomes apparent that all three aspects of vocabulary building, which S.P.E. Boshoff identified as "erfgoed", "eiegoed" and "leengoed" in 1921 (Eksteen 1984: 144), come into play. Words were certainly inherited from their ancestral Malayo-Polynesian family of languages; words were also borrowed from Arabic, English and Dutch to extend their core vocabulary. Then, too, there is definite evidence of concept construction. This creative process of neology helped to accurately project their theo-philosophical thoughts.

\section{INHERITED AND BORROWED LEXICAL UNITS AND ITEMS}

As already noted, the core vocabulary of Afrikaans comes from Dutch. Cape Muslim Afrikaans, as a variety of Afrikaans, is also dependent on this Dutch core vocabulary for its essential communication. It, however, also borrowed extensively from Arabic, the religious language of this community, and the language from which theological tracts were translated.

Cape Muslim Afrikaans also, to a lesser degree, borrowed from other languages like French and English with which it came into contact. French accounted for such words as aspris (on purpose, from French - expres); kardoesie (packet, from French - cartouche); sa-vette (towels, from French serviette) and tamaletjie (a sweet, from French - tablette).

The French etymological origins of these words were already determined by Changuion in 1844 (viii, xiv, xxiii). From the Arabic-Afrikaans publications I have picked up some English words such as saimde (the same) (Effendi 1894); promis (promise) (Gamieldien 1910), davarent (different) (Behardien 1918), and ghamixte (mixed) (Abdurakib ibn Abdul Kahaar 1898).

Then, too, Cape Muslim Afrikaans inherited vital lexical items from the Malayo-Polynesian family of languages which the ancestors of its speakers brought with them as slaves from South East Asia. There seems to be an interesting pattern with regard to the borrowing and inheritance of lexical items and units.

From the available Arabic-Afrikaans literature, except maybe for the Tuhfatul Ahwam (A gift for friends), written by Abdul Kahaar ibn Abdul Malik in Port Elizabeth in 1868, Arabic seems to be the preferred language for borrowings. The spoken Cape Muslim Afrikaans, on the other hand, is again freely laced with lexical units and items inherited from their 
Malayo-Polynesian linguistic past. It is, in any case, these inherited lexical units which make Cape Muslim Afrikaans a distinctive Afrikaans variety, but, nevertheless, still related to the broader family of Cape Afrikaans. Its distinctiveness as a variety, with identifiable lexical units from its ancestral slave languages, seemed to have already been acknowledged by Suasso de Lima (1844: 9) when he, in protestations against Changuion's word list, writes:

Meent de geleerde Heer dat het Kaapsch taaleigen door hem aangehaald de taal is der Hottentotten, dan moeten wij zijn Edele andermaal een groot kompliment maken, want het bewijst dat zijne overgroote aanraaking met die onbeschaafde volksklasse van groote uitgestrektheid geweest is - maar dit gaat mank - want wij vinden in die lijst bij voorbeeld:

\section{Allah! God, een Turksch woord}

Aja, (Maleidsch) en andere derglijke Maleidsche woorden meer.

Some of these inherited Malayo-Polynesian lexical units were absorbed into the vocabulary of Standard Afrikaans. Words such as baadjie, baie, pondok, kapok, katjiepiering, ghomma, kaparang, kris, blatjang, nonna, baklei (Eksteen 1984: 150, 151) today constitute part of the vocabulary of Standard Afrikaans. To the words listed by Eksteen I can add krabbetjie, tjap, tjommel, tamaai, amper and kabaai. Other words which were inherited from the Malayo-Polynesian family of languages have remained only in Cape Muslim Afrikaans.

A list of these words, with their etymological origins and Cape Muslim Afrikaans meaning, is here produced:

\section{Cape Muslim Afrikaans}

abdast [abdas] (noun)

agama [axa:ma] (noun)

atjar [açar] (noun)

bakaiyer [bakəijər]

(verb)

bang [bay] (verb)
Etymological origin

from Persia to Malayu

Sanskrit = agaama

Sunda $=$ atjar

Malayu = bakai-er

Malayu = bang
Meaning and usage

spiritual ablution

religion

fruit/vegetable pickles

playing with the swords during the Ratiep performance

giving the call for prayer 
barakat $[$ barakat] (noun) $\quad$ Malayu $=$ berkata

Malayu = batja

Sunda $=$ bingu

biengoe [bin'gu]

(abstract noun)

boeka [buka] (verb)

\section{djalantoes}

[dzalantus]

(abstract noun)

djamang [dzaman]

(noun)

djapandoelie

[dzapanduli]

(adjective)

ghabaar [xaba:r] (noun)

ghielap [xilap] (verb)

ghoentoem [xuntum]

(verb)

graana [xra:na] (noun)

hiempoe [himpu] (noun)

kafang [kafay] (noun)

kalie [kali] (noun)

kanalla [kanala] (noun)
Malayu $=$ himpun

Malayu = kafan

Sunda $=b u k a$

Malayu $=$ djala

melang

Sunda = djamban

Malayu = djamaduli

Malayu $=$ cheddar

Malayu $=$ kilat

Malayu = guntur

Sanskrit = grahana

eclipse

to bring together as one (one congregational prayer)

linen used as a shroud of the dead

river

Malayu $=$ kama $\quad$ please

Allah 


\begin{tabular}{|c|c|c|}
\hline $\begin{array}{l}\text { kiefai-jat [kifai'jat] } \\
\text { (noun) }\end{array}$ & Malayu = kifaiyah & funeral \\
\hline $\begin{array}{l}\text { labarang [labaran] } \\
\text { (noun) }\end{array}$ & Sunda $=$ lebaran & $\begin{array}{l}\text { general name for } \\
\text { Eid, the two major } \\
\text { religious festivals }\end{array}$ \\
\hline lambar [lambar] (verb) & Malayu $=$ lamar & $\begin{array}{l}\text { to become engaged } \\
\text { to be married }\end{array}$ \\
\hline lang-ar [lag'ar] (noun) & Malayu = langgar & prayer room \\
\hline $\begin{array}{l}\text { lanja [landza] } \\
\text { (abstract noun) }\end{array}$ & Sunda $=$ lantjang & $\begin{array}{l}\text { to be fluent in the } \\
\text { recitation or in } \\
\text { memorization }\end{array}$ \\
\hline $\begin{array}{l}\text { lat-tjoe [lat'cu] } \\
\text { (abstract noun) }\end{array}$ & Malayu = latjur & $\begin{array}{l}\text { bad luck: Hy kan } \\
\text { nooit wen nie, hy } \\
\text { is lat-tjoe }\end{array}$ \\
\hline ling-oe [lin'u] (noun) & Sunda $=$ lin $\boldsymbol{~}^{-} u$ & $\begin{array}{l}\text { A Balanese cushion } \\
\text { dance which was up } \\
\text { to } 30 \text { years ago still } \\
\text { popular at the Cape }\end{array}$ \\
\hline $\begin{array}{l}\text { manieng-al [manin'al] } \\
\text { (verb) }\end{array}$ & $\begin{array}{l}\text { Malayu = mening } \\
\text { gal }\end{array}$ & to have died \\
\hline mannie [mani] (verb) & Malayu $=$ mandi & to bath \\
\hline mantra [mantra] (verb) & Sanskrit = manter $a$ & spiritual healing \\
\hline $\begin{array}{l}\text { maskawi [maskavi] } \\
\text { (noun) }\end{array}$ & Malayu = maskawin & dowry \\
\hline merang [meran] (noun) & Malayu = rame'an & feast \\
\hline mesang [mesan] (noun) & Malayu $=$ mesan & tombstone on grave \\
\hline $\begin{array}{l}\text { mienta [minta] } \\
\text { (abstract noun) }\end{array}$ & Malayu $=$ mintaken & $\begin{array}{l}\text { hope: Ek mienta } \\
\text { dat jy ' } n \text { lekker } \\
\text { reis sal hê }\end{array}$ \\
\hline
\end{tabular}




\begin{tabular}{|c|c|c|}
\hline $\begin{array}{l}\text { mienta-maaf or } \\
\text { boeta-maaf (adverb) }\end{array}$ & $\begin{array}{l}\text { Malayu = minta }- \\
m u^{\prime a a f}\end{array}$ & excuse me \\
\hline moeli-at [muli'at] & Malayu $=$ melihat & watch-out! \\
\hline motjie [moc̃i] (noun) & Javanese $=$ muntjie & woman or wife \\
\hline pang [pay] (noun) & Malayu = bapang & man or uncle \\
\hline pasang [pasan] (verb) & $\begin{array}{l}\text { Malayu = pasang } \\
\text { telinga }\end{array}$ & $\begin{array}{l}\text { to announce: Salie } \\
\text { het gepasang vir } \\
\text { die kiefai-yat }\end{array}$ \\
\hline piejara [pidzara] (noun) & Malayu = petjara & $\begin{array}{l}\text { conference or } \\
\text { meeting }\end{array}$ \\
\hline poervasa [puwasa] & Sanskrit = puwasa & to fast, or fast \\
\hline sadjie [sad'c̄i] (verb) & Sanskrit = sajjiker & to serve \\
\hline samba [samba] (verb) & Malayu = sambar & $\begin{array}{l}\text { to be inflicted with } \\
\text { an evil spirit }\end{array}$ \\
\hline slamat [slamat] & Malayu = selamat & congratulations \\
\hline soembai-ing (verb) & $\begin{array}{l}\text { Malayu = sembah }- \\
\text { jang }\end{array}$ & to pray \\
\hline soempa [sumpa] (verb) & Malayu $=$ sumpah & to make an oath \\
\hline soppang [sopay] (adverb) & Bughies = suppang & dignified \\
\hline tjaija [c̈əija] (noun) & Sanskrit $=$ chấ-yâ & $\begin{array}{l}\text { face: Sy het 'n } \\
\text { mooi tjaija }\end{array}$ \\
\hline toelies [tulis] (verb) & Malayu = tulis & to write \\
\hline top [top] (noun) & Javanese $=$ tup-ake & a prayer shirt \\
\hline tramakasie [tramakasi] & $\begin{array}{l}\text { Malayu = terima } \\
\text { kasih }\end{array}$ & thank you \\
\hline
\end{tabular}

Though Malayu predominates as the language of origin of these inherited lexical units, it is also interesting to note the influence of Sanskrit. This could be 
attributed to the tremendous contact which the Malayo-Polynesian languages had with Hinduism prior to the advent of Islam in the region; and the influence which Sanskrit exerted not only on the writing traditions and alphabets, but also on the vocabularies of the languages of the south east Asian Archipelago (Crawfurd 1820). These inherited Malayo-Polynesian lexical units, however, have been completely bridged into the spoken Afrikaans of the Cape Muslims, but in this process of bridging they have also changed in their pronunciation. They have become so Afrikaans in sound that they, at times, are not immediately recognized by speakers of the language from which they were originally inherited.

But apart from such direct appropriation with orthoepic change, some Malayo-Polynesian lexical units inherited, changed to perform new syntactical and grammatical functions in Cape Muslim Afrikaans. Thus the Malayu verb slamblee (to slaughter) would take on the Afrikaans grammatical morpheme er, to form the noun slamblie-er. Similarly the Buganese derived verb soppang (dignified), with affixing of the Afrikaans grammatical morpheme heid, becomes an abstract noun soppangheid (dignity). Another example is the affixing of the Afrikaans grammatical morpheme se to the Malayu word djapandoelie (ancient) to form the adjective djapandoeliese in the lexical item djapandoeliese tyd (for 'ancient time'). Or merely by changing the word order of composites, which in the Malayo-Polynesian syntactical arrangements is for the noun to be followed by the adjective, to conform more closely with the Afrikaans syntactical patterns, a new distinctive Afrikaans ring to a Malayo-Polynesian composite is created. The classical example is mannie-kamer (bathroom) from the Malayu kammar-mandi, where the adjective mandi, meaning bath, follows the noun kammar, meaning room.

The more extensive use of Arabic loan words, and the relative absence of Malayo-Polynesian inherited lexical items, in the Arabic-Afrikaans publications could be attributed to two main factors. The vast majority of the Arabic-Afrikaans publications produced were translations from Arabic. It would have been easier to have borrowed words from this language than from any of the Malayo-Polynesian languages. In any case many of the basic Arabic-Islamic religious terms were already absorbed into Malayu, the religious language of the Cape Muslims in the beginning of the nineteenth century. It was possibly through Malayu that such Arabic terms as salaah (prayer); niekah (marriage ceremony); zakaah (the poor rate); kiefai-jat (funeral); masjied or masiet (mosque); niesaab (taxable property); rieziek (bounty); daleel (Quranic substantiation) and waajieb (necessary) were absorbed into Cape Muslim Afrikaans.

At the time when the majority of the Arabic-Afrikaans publications were embarked upon, Malayu was no longer a spoken language in Cape Town. In 1903, Hiesham Neamatullah Effendi claimed: "Their language used to be the Malay language. They have lost it. They are a Dutch speaking community of different nationalities and races ..." (Cape Times, 20 March 1903). In view of this evidence, 
one could well understand that it would have been foolhardy, therefore, to seek loan words from Malayu, or for that matter, any other of the MalayoPolynesian languages to explain the Arabic religious concepts. The objective of the translators was the transmission of religious ideas. This could only be achieved by a language medium comprehensible to their target community. The Malayo-Polynesian terms for the Islamic religious concepts, which were already in use, and bridged into their spoken Afrikaans, were effectively appropriated. This is evident in the fact that the word mannie (Malayu = bath), coexists with ghoesl (Arabic = bath) [gusl]; and abdast (Malayu = spiritual ablution) with woedoe (Arabic) in the Arabic-A frikaans publications.

The interdependency of the Malayo-Polynesian and Arabic languages in the creation of Afrikaans equivalents for the Arabic religious concepts are no more clearly seen than in the creation of composites. Examples of these composites are graana-salaah (prayer for the eclipse) - a Sanskrit-Arabic combination; kierie-slaam (best greetings) - a Sunda-Arabic combination; while tuan-koeber (gravedigger) is an Arabic-Malayu combination.

Arabic loan words in Cape Muslim Afrikaans came mainly via the ArabicAfrikaans publications. Not all of the Arabic words borrowed became bridged into Cape Muslim Afrikaans. The custom, as in other languages, not to translate the fundamental concepts and keywords of Islamic thought from Arabic, however, also led to these key words and concepts immediately becoming part of Cape Muslim Afrikaans. Hence it is difficult to say whether such key words as malaa'iekat (angels); kietaab (book); siefaah (attribute); and dja-iez (acceptable) were brought directly into Cape Muslim Afrikaans from Arabic. These key words and concepts could have come into Cape Muslim Afrikaans via one or other of the Malayo-Polynesian languages.

Not all words borrowed from Arabic in the Arabic-Afrikaans publications came to constitute part of the vocabulary of the Cape Muslims. Many of the borrowed words have a rather restrictive religious meaning, and cannot be easily used in colloquial communication. Such words would not be deemed to constitute part of Cape Muslim Afrikaans, despite their usage in the ArabicAfrikaans publications. Some other Arabic words with restrictive meaning were, however, absorbed into Cape Muslim Afrikaans by virtue of their extensive usage. Such words are: talak (divorce); salaah (prayer); goedbah (sermon), which by the mere affixing of an Afrikaans grammatical morpheme, can perform different syntactical functions. Hence talak can become getalak (divorced $=$ a past tense) or talakke (divorces $=$ a plural), salaah can become gesalaah (prayed), and goedbah can become gegoetbah (read the sermon), indicating the past tense action of the verb. Then, again, Arabic words like mansoogh (abrogation, but used in the sense of 'it is settled'), soelg (to make amends), kiesa (story), which do not really change morphologically with syntactical or grammatical function, are so extensively used in both secular and religious communication, that they are assumed to be Afrikaans. 
There are, however, also other words which came into Cape Muslim Afrikaans via the Arabic-Afrikaans publications. Many of these words have a Malayo-Polynesian equivalent which seems to be preferred in the colloquial Cape Muslim Afrikaans. Thus the verb soembai-ing (Malayu) is preferred to salâti, the Arabic verb for 'prayer'. Similarly soeboeg (Malayu), as the name for the morning prayer, is preferred to Arabic fajr. It is always poewasa (Malayu) for the act of fasting, seldom soum, its Arabic counterpart. We also talk of maskawie (Malayu), instead of mahr, the Arabic for 'dowry'. There are many such examples.

The strength of the bridging of an Arabic word into Cape Muslim Afrikaans appears to be determined by the grammatical usage of such words through the affixing of Afrikaans grammatical morphemes. The changes in grammatical function are indicated, for example, with Arabic root words such as:

nabee (prophet) - noun + skap $=$ nabeeskap (prophethood) - an abstract noun;

nieyat (to make intention) - verb $+g e=$ genieyat - a past tense verb;

saheeh $($ correct $)-$ noun + ste $=$ saheehste $($ the most correct $)$ - an ad verb;

hoekoem (ruling) - noun $+s=$ hoekoems (rulings) - a plural;

waadjieb (necessary) - adjective + heid $=$ waadjiebgheid (necessity) - an abstract noun.

It would appear that it is the morphological change for a new syntactical function which indicates the intensity of the integration of an Arabic loan word in Cape Muslim Afrikaans.

\section{NEOLOGISMS}

Probably the most creative aspect of vocabulary building was through the process of neology. Apart from the affixing of morphemes to change the grammatical function of inherited lexical items and other loan words bridged into Cape Muslim Afrikaans, words were also created to convey exclusive meanings. Typical examples are werksloon and maaksloon. In both these examples the Afrikaans word beloning is interpreted to mean 'reward from God'. Thus in the first instance werksloon would imply 'activities for which God will reward the individual' (i.e. such as prayer or indulgences in spiritual activities). The word, however, also acquired the meaning 'good deeds', and it is in this sense that it is currently more frequently used. Similarly maaksloon, which means 
'creation', also has the implied meaning that the process of creation is a reward for humanity.

The word warraiskap was specifically created by Imam Abdurakib ibn Abdul Kahaar (1898) to convey the deep sense of psychological worry which results from a state of spiritual impurity - and thus he writes: "om wegh te niem die warraiskap wat kom van gadath of onrainnighaid" (See Davids 1991: 135). Hisham Neamatullah Effendi (1894) created the word opbouwens, as a concept for 'systematic construction', and Imam Abdurahmaan Kassiem Gamieldien (1907: 2) coined the word verghinskap for a 'divine gift of providence'.

One of the Arabic-Afrikaans writers most creative with neologisms is Sheikh Abdullah Ta Ha Gamieldien. His creativity is particularly evident in his 1910 translation of the Matha 'il abi Laith (The questions of Abi Laith), a philosophical exposition on the dogma of belief by the tenth century Islamic philosopher Nasr ibn abi Laith al-Samaqandi. To convey the philosophical meanings of the Arabic concepts expressing the attributes of God, Taha Gamieldien embarked on an ingenious process of neology to create powerful Afrikaans nouns. These nouns very effectively expound the perceived functional meaning of God as conveyed by the Arabic concepts.

Thus, as a translation for the Arabic word bâqin, which comes from the theological concept baqâ, which means that 'God has neither a beginning nor an end', he creates the word aitwaghdieren. In terms of the Arabic dictionary (Hans Wehr 1980: 68), baqâ is defined as 'eternal' or 'immortality'. To convey the idea that God is eternal, Ta Ha Gamieldien uses the Dutch uitwacht, which conveys an idea of 'out watching', as his core word and adds the Dutch morpheme deren to change its grammatical function from a verb to an abstract noun. Aitwaghdieren is a particularly interesting word, virtually telling you, no matter how patient you are, God will outwait you in the final consideration.

Similarly, as a translation for the Arabic âlimun (the All-knowledgeable), he creates the word wieter, conveying the feeling that God alone is knowledgeable of all things. For the Arabic qâdirun (the All-powerful), the new word kraghtagh is used; while the Islamic concept of predetermination is brilliantly conveyed by the created word wiler (the One who Wills) for the Arabic concept muridun, a noun which expresses the idea 'that everything is predetermined by the Will of God'.

From the translation of the Matha il abi Laith it is obvious that such lexical units as gienage, from the Dutch diegene, instead of the Standard Afrikaans die ene; liewendag, instead of the Standard Afrikaans lewende; Maker, instead of the Standard Afrikaans Skepper - in reference to God; and afgekom instead of openbaar (revealed) were already established language usage in Cape Muslim Afrikaans in 1910. Ta Ha Gamieldien also illustrates how willing the Arabic-Afrikaans writers were to create Afrikaans abstract nouns by affixing the grammatical morphemes heid and skap to existing verbs. This is seen in such lexical units as strygeit, tweizvelheid and afriekenskap. 
It was through the creation of composites that neologisms greatly enriched the limited vocabulary of the Cape Dutch or Cape Afrikaans which the early Cape Muslim Arabic-Afrikaans writers had at their disposal. These composites in turn enriched the vocabulary of Cape Muslim Afrikaans. All kinds of language combinations in the creation of such new words exist. Here follow a few examples showing how the combination of lexical units from different languages creates new lexical units for Cape Muslim Afrikaans:

abdasplek (place for ablution) = abdast (Malayu) + plek (Afrikaans)

boekatyd (time to break the fast) = boeka (Malayu) + tyd (Afrikaans)

denningoleis (a meat stew) $=$ denning (Malayu) + vleis (Afrikaans)

koeberplaas (burial ground) = koeber (Arabic) + plaas (Afrikaans)

korbaanvleis (sacrifice meat) = korbaan (Arabic) + vleis (Afrikaans)

labarangbox $($ Eid present $)=$ labarang $($ Malayu $)+$ box $($ English $)$

labarangsuit $($ Eid suit $)=$ labarang $($ Malayu $)+$ suit $($ English $)$

mie-angtessie $($ incense pot $)=$ mie-ang $($ Malayu $)+$ tessie $($ Afrikaans $)$

ouwal-moereeds (first members) $=$ ouwal (Arabic) + moereeds (Arabic)

poewasa-aramanakie (Ramadaan calender) = poewasa (Malayu) + aramanakie (English - from almanac)

rizieq-giever (giver of bounty) = rizieq (Arabic) + giever (Dutch)

soeboegsalaah (morning prayer) $=$ soeboeg (Malayu) + salaah (Arabic)

soembai-ingtapyt (prayer mat) = soembai-ing (Malayu) + tapyt (Afrikaans)

tuankoeber (gravedigger) = tuan (Malayu) + koeber $($ Arabic $)$

zakaatmaker (giver of charity) = zakaat (Arabic) + maker (Afrikaans)

zie-jaaratplekke (places of pilgrimage) = zie-jaarat (Arabic) + plekke (Afrikaans)

An interesting observation from the composites is that, where the components are both derived from Arabic, the syntactical functions of the words are 
switched to conform to the Afrikaans, rather than the Arabic, syntactical arrangements. It is normal in Arabic, as with the Malayo-Polynesian languages, for the noun to be followed by the adjective. Thus one talks of Sheikhun-kabir (the great sheikh) or kitâbun-aswadun (the back book) which, in a direct translation, would read: Sheikh-great and book-black respectively.

Following therefore the Arabic order of syntax, ouwal-moereeds (first members); asal-niesaab (original taxable property) and waajieb-niesaab (necessary tax) should read moereed-ouwal; niesaab-asal; and niesaabwaajieb. This does not happen. With the creation of these composites the syntactical arrangements of Afrikaans are observed.

\section{COMPLEX LEXICAL ITEMS — IDIOMS AND EXPRESSIONS}

Given the kind of linguistic situation the Cape Muslim community found themselves in, and considering the limitation of the language code at their disposal, the Cape Muslims had to exploit the communicative potential of this restrictive code to arrive at utterances which most appropriately satisfy their communicative needs. The speaker, Langacker (1973: 54) tells us, has to make his language fit the situation, no matter how unusual. He therefore has, on occasions, to construct a phrase or a sentence in order to express a meaning which a single word is unable to express. It is with the creation of such phrases and sentences - which with regular use come to convey precise meanings as idioms and expressions - that linguistic creativity and diversity grows. In a sense, to be creative in language, one needs to be innovative. In this regard, the Cape Muslim community has indeed been innovative in its spontaneity with its idioms and expressions.

Idioms and expressions very much constitute part of the lexical inventory of a language. In fact, Eksteen (1984: 137) argues that the lexicon of a language is composed of its words, its morphemes and its idiomatic expressions. It is, however, in the creation of its idiomatic expressions that a language creatively utilizes its words and morphemes. Thus, it is their creation of idioms and expressions which shows the ingenious creativity of the Cape Muslims with the perceived limitations of Cape Dutch or Cape Afrikaans. It is also their creativity with idioms and expressions which gives Cape Muslim Afrikaans its humour. These idioms and expressions, despite their lack of sophistication at times, facilitate the flow of Cape Muslim Afrikaans as an effective means of communication. Hence to show their total adequacy, members of the Cape Muslim community will jokingly say:

' $n$ Boer maak ' $n$ plan, maar ' $n$ Slams het ' $n$ plan (A boer makes a plan, but a Muslim has a plan) 
Here follow some examples of Cape Muslim Afrikaans idioms and expressions:

aansit: Sy kan baie aansit as sy praat $=$ She is very pretentious when she speaks. Alternatively: $\mathrm{Hy}$ is vol aansit $=\mathrm{He}$ is full of pretense. Sometimes also used as: Hulle is baie aansitterag $=$ They are full of pretense.

aspris: Iy lewe aspris $=$ You live without purpose.

brêggat: Hy's 'n ou brêggat = He is a braggard.

bus: $S y$ is bus = She is a busybody.

busry: Hou weg van dai vroumense, hulle kan heeldag busry = Stay away from those ladies, they gossip the whole day.

die toit: Hoe gaan dit met die toit? = How is your wife keeping?

gesig verkoep: Dit help nie om gesig te verkoep nie = It does not help to curry favour. Simply: Jy verkoep gesig (ghasegh) or Jy verkoep gevreet (ghavriet).

huisbou: Moenie huisbou nie, man, kry klaar met jou storie = Don't drag it out, get done with your story.

kart skiet: Jy het hom darem 'n kwaai kart geskiet = You told him a fantastic story (which he believed but which might not necessarily be true).

kastai: Die kind kan ' $n$ mens baie kastai = This child can really tease you.

kêpies is berêtjies: Wat dink jy kêpies is berêtjies? = These things (or problems or tasks) may look the same, but there are subtle differences between them.

kop: Waar kry jy dai kop? = You must be out of your mind (that idea can never work).

kwaai lappies: Kwaai lappies! = Well done!

laa die daa: Hulle is laa die daa mense = They are upper class people. (Also: Hulle is bakgat mense.)

laai-laai: Sy is baie laai-laai $=$ She is very cheeky, or: She has a sharp tongue.

lekker bêt: Hy kan lekker bêt = He eats well. 
luisgat: Hy is 'n ou luisgat, jong = He is a no-good, or: He won't work, or: $\mathrm{He}$ is unreliable.

manieng-al: Is jou brein dan gemanieng-al? = Are you really that stupid? A literal translation: Is your brain dead?

on-er karte: Hy is on-er karte = He has all kinds (not necessarily true) stories to tell you. Also used to indicate that a person is a good conversationalist and that he is good company.

oppie tippie: Iy is altyd soe oppie tippie = You always wait till the last moment.

ougat: Sy is tog te ougat = She is so cute.

poenang-kies: Dis nou baie poenang-kies = Now that is pretty. (The expressions poenang-kies and ougat are used interchangeably.)

poep op 'n lappie: Hy is maar net 'n poep op ' $n$ lappie = He is absolutely nothing.

pop: Wat dink jy ek is ' $n$ pop? = Do you take me for a fool?

reent: Waar slaap jy as dit reent? = Where do you come from? Normally used when someone says something stupid or inappropriate.

slamblee: Iy kannie sy slamblee vriet (eet) nie = You cannot trust him.

spaai: Moenie my vat vir 'n spaai nie = Don't underestimate me.

tang a lang: Kry klaar, jy tang a lang te veel = Get done, you are wasting too much time.

toe: $I y$ is so toe soes OK op Sondags = You have no comprehension of what is happening around you. Usually the expression is simply used as: Jy's toe.

In the vocabulary of Cape Muslim Afrikaans lexical items from both the IndoGermanic and the Malayo-Polynesian families of languages are evident. These lexical items show the strong influence that these two families of languages had on the genesis of Afrikaans. This places Afrikaans in a unique position of being the only modern language which can claim ancestry from the contact of different families of languages. Here at the Cape the Indo-Germanic and Malayo-Polynesian language families, which have a common ancestor in Sanskrit, made contact with Khoesan. The common denominator was the domi- 
nant syntactical arrangement of the different languages spoken at the Cape. This syntactical arrangement follows essentially the SOV (subject-object-verb) word order. The Germanic Dutch thus had the same syntactical arrangement as the Malayo-Polynesian languages of the slaves and indigenous Khoesan.

This allowed for easy word switching from one language to another within a constant syntactical framework. It, however, means that the inherited lexical items or erfgoed of Afrikaans are not only derived from Dutch. The lexical item baie (many), for instance, is not borrowed but inherited from Malayu. Its extensive usage in the Afrikaans language testifies to this fact. The concepts "erfgoed", "eiegoed" and "leengoed" formulated by Boshoff (Eksteen 1984: 144) are, therefore, in need of a serious re-appraisal. "Erfgoed" are not necessarily only those lexical units and items which came into Afrikaans via the Germanic Dutch.

Most of the lexicons of Afrikaans are more exclusive than inclusive. In the compilation of the lexicons, emphasis is placed on words which are generally accepted in Standard Afrikaans. Many lexical items of the non-standard varieties of Afrikaans seem to be ignored or are unknown to the compilers. This in turn has implications for philological studies on the genesis of Afrikaans. In the case of Cape Muslim Afrikaans, its distinctive lexical units and items are not only evident in the spoken, but also in the written language of the Cape Muslim community. Then too, Cape Muslim Afrikaans is used to convey moral and religious ideas in their places of worship and other religious institutions. Such usage of a language and its lexical items shows evidence of sophistication. Therefore, Cape Muslim Afrikaans cannot be regarded as "uncivilized". In view of this, the lexical items and units of Cape Muslim Afrikaans need to be recognized and a lexicon of Cape Muslim Afrikaans formulated. The more extensively used distinctive lexical units of Cape Muslim Afrikaans must be incorporated into Standard Afrikaans.

\section{CONCLUSIONS}

What this essay shows is that apart from the recognized differences in pronunciation between Cape Muslim and Standard Afrikaans, there are also marked differences in their vocabularies. Cape Muslim Afrikaans also depends on Dutch for its core vocabulary. Unlike Standard Afrikaans, it has retained many lexical units of Cape Afrikaans which existed prior to standardization. Furthermore, it inherited some lexical units from the ancestral slave languages of its speakers and borrowed others from the languages with which it came into contact at the Cape. Arabic began to make contributions to its lexical inventory when Arabic theological tracts were being translated into their mother tongue, Cape Muslim Afrikaans.

These translations necessitated the creation of new lexical units to facilitate the expression of the involved theo-philosophical ideas. 
All this led to Cape Muslim Afrikaans having a lexicon of its own. This essay looks at only some aspects of that lexicon, and notes some of its lexical units and items. There are some lexical units, like gesitnaai for the Standard Afrikaans naai or naaizverk, and nêmatjies for the Standard Afrikaans netnou, though still extensively used, which are not even discussed. Some of these lexical units already existed in nineteenth century Cape Muslim Afrikaans. My first observation, therefore, is that there is no complete lexicon of Cape Muslim Afrikaans. Such a lexicon may broaden our understanding of Cape Afrikaans and hopefully lead us to re-evalute some of the existing philological studies dealing with the genesis of Afrikaans.

The borrowing and inheritance of lexical units from the ancestral slave languages and languages of contact with Cape Muslim Afrikaans did not constitute a simple process. It involved complicated morphological, syntactical and phonological adaptations so that these lexical units, at least in orthoepic practice, conform to the acoustic nature of Cape Muslim Afrikaans. This is evident from the changes in pronunciation of the lexical units inherited from the Malayo-Polynesian ancestral languages. It is even more evident in the way grammatical and lexical morphemes are used as affixes to create for these "foreign" words new syntactical functions and new orthoepic sounds. The results of this is that gemixte, for instance, hardly sounds English in Cape Muslim Afrikaans.

Cape Muslim Afrikaans, as a distinctive variety of Afrikaans, only survived because it acted as a vehicle for the transmission of religious ideas. It was the medium of instruction in the Islamic religious schools or madaris, the language for lectures and translations of the sermons in the mosques. Its extensive use for religious purposes in turn strengthens its usage for social communication. But it was its use as the medium for written communication, although in the Arabic script, which facilitated the dissemination and helped the perpetuation of its lexical inventory. The dissemination and perpetuation of its lexical inventory were further facilitated by the fact that its speakers became a reading community. By 1925 the Cape Muslims were considered one of the most literate Muslim communities in the world (Zwemer 1925: 349). Already as early as 1874, Cape Muslim Afrikaans, in Arabic script, was used for the writing of a love letter from Turkey. In terms of the lexical units in this letter, it would appear as if the phonology and lexicon of Cape Muslim Afrikaans have not changed considerably over the years. A few lines from this letter transcribed from the Arabic script read as follows:

main twee oe-ge en liefste motjie onsain groeroot god wat vir ons ghamaak sain seeghint en virghifnis is op ouai en op main liefste broer ('Abeed). main haart is tiedaagh seer om ek kanie vir ouai sien voor ek wegh gaan. ek versoek van groote god om vir ouai weer te sien ... (Lutfie-Effendi 1991:3) 
Finally, I suggest that there is a need for a compilation of a comprehensive lexicon of Cape Muslim Afrikaans. Such a lexicon will take several researchers a considerable time to compile. It is my hope that this essay is a positive start in that direction.

\section{REFERENCES}

Abdul Kahaar ibn Abdul Malik 1868. Tuhfatul Ahwam (A Gift for Friends). Unpublished Manuscript.

Abdurakib ibn Abdul Kahaar. 1898. Kitab ar-riad al badia (The Book of the Wonderful Garden). Cape Town: Afrikaansche Drukkerij.

Behardien, Sheikh Achmad. 1918. Su'al wa jawab (Questions and Answers). Bombay: Nurudin Press.

Brandel-Syrier, M. 1960. Religious Duties of Islam as Taught and Explained by Abu Bakr Effendi. Leiden, Pretoria: Oriental Studies.

Cape Times, Cape Town, 20March 1903.

Changuion, A.N.E. 1844. De Nederduitsche Taal in Zuid Afrika Hersteld sijnde eene Handleiding tot de Kennis dier Taal, naar de plaatsselijke behoefte van het land gewijzigd. Cape Town: J.H. Collard.

Crawfurd, J. 1820. History of the Indian Archipelago. (3 volumes). Edinburgh: Archibald Constable.

Davids, Achmat. 1990. Words the Cape Slaves made: A Socio-historical linguistic study. South African Journal of Linguistics 8(1): 1-24.

Davids, Achmat. 1991. The Afrikaans of the Cape Muslims from 1815 to $1915-$ A Socio-linguistic Study. Unpublished M.A. thesis, University of Natal, Durban.

De Lima, J. Suasso. 1844. De Taal der Kapenaren tegen de schandelijke derzelve oan Professor Changuion. Cape Town: J. Suasso de Lima.

Effendi, Abubakr. 1869. Bayanudin (An Explanation of the Religion). Constantinople: Sublime Porte.

Effendi, Hisham Neamatullah. 1894. Hatha 'ilmuhal-lis-sibyan (This Wonderful Knowledge Explained). Constantinople: Uthmaniyah Press.

Eksteen, L.C. 1984. Die Afrikaanse woordeskat. Botha, T.J.R. (Editor-in-Chief), J.G.H. Combrink and F.F. Odendal. Inleiding tot die Afrikaanse Taalkunde. 1984. Pretoria: Academica.

Elffers, H. 1908. The Englishman's Guide to the Speedy and Easy Acquirement to Cape Dutch. Cape Town: Juta.

Gamieldien, Abdullah T.H. 1910. Matha il abi Laith (The Question of abi Laith). Cape Town: Muslim Improving School/Cape Argus.

Gamieldien, Abdurahman K. 1907. Tartibus-Salah (Perfection in Prayer). Cape Town: Al Azhar Mosque Madrasah.

Hahn, Theophilus. 1882. On the Science of Language and its study, with special reference to South Africa. Cape Town: S.A. Library - South African Bound Pamphlets.

Langacker, Ronald W. 1973. Language and its Structure - Some Fundamental Linguistic Concepts. New York: Harcourt Brace Jovanovich. 
Logeman, W.S. 1903. Cape Dutch. Cape Town: South African Association of Science, SA Library - South African Bound Pamphlets.

Lutfie-Effendi, Omar. 1991. A Travelogue of my Joumey to the Cape of Good Hope. (Forword by: Sheikh Abubaker Najaar). Cape Town: Al-Khaleel Publications.

Manuscript (Author unknown). 1860. Exercise Book of Lessons (koples). By a Student at the Dorp Street Madrasah.

Muller, P.J. 1960. Afrikaanse geskrifte in Arabiese karakters. Bulletin of the South African Library 15(3): 34 .

Swaving J.G. 1830. Swaving's Zonderlinge Ontmoetingen na Zijne Vlucht uit Delft. Dordrecht: Blusse en van Braam.

Teenstra, M.D. 1830. De Vruchten Mijner Werkzaamheden, Gedurende Mijne Reize, Over de Kaap de Goede Hoop, Naar Jooa, En Terug, Over St. Helena, Naar de Nederlanden. Groningen: H. Eekhoff.

Valkhoff, Marius. 1966. Studies in Creole and Portuguese with Special Reference to South Africa. Johannesburg: Witwatersrand University Press.

Wehr, Hans. 1980. A Dictionary of Modem Written Arabic (Arabic - English). Milton Cowan, J. (Ed.). Beirut/London: Libraire du Liban - MacDonald and Evans.

Zwemer, S.M. 1925. Two Moslem Catechisms (published at Capetown). Moslem World, London. 